\title{
Growth analysis of the Pacific sierra Scomberomorus sierra in Colima, México
}

\author{
Análisis del crecimiento de la sierra del Pacífico Scomberomorus sierra en Colima, México
Rubí A. Nava-Ortega ${ }^{1}$, Elaine Espino-Barr², Manuel Gallardo-Cabello ${ }^{3}$, Arturo Garcia-Boa $^{2}$, Marcos Puente-Gómez ${ }^{2}$ and Esther G. Cabral-Solís ${ }^{2}$

\begin{abstract}
${ }^{1}$ Instituto Nacional de Pesca, Centro Regional de Investigación Pesquera-Bahía Banderas, Calle Tortuga 1, La Cruz de Huanacaxtle, Nayarit, C.P. 63732, México

${ }^{2}$ INAPESCA, CRIP-Manzanillo, Playa Ventanas s/n, Manzanillo, Colima. C.P. 28200, México. elespino@gmail.com ${ }^{3}$ Instituto de Ciencias del Mar y Limnología, Universidad Nacional Autónoma de México, Av. Ciudad Universitaria 3000, Col. Copilco, México, D.F. C.P. 04360, México
\end{abstract}

Resumen.- La pesca artesanal de la sierra Scomberomorus sierra capturada en la costa de Colima representa el 1\% de la captura total. De enero 2003 a marzo 2004 se obtuvieron datos morfométricos de 972 ejemplares y otolitos de 464 especímenes que se utilizaron para analizar edad y crecimiento. Se analizó por dos métodos: análisis de frecuencia de longitud y estudio de otolitos sagittae y asterisci por lecturas directas. Ambos métodos identificaron 5 grupos de edad. Las constantes de crecimiento de la ecuación de von Bertalanffy se determinaron por los métodos Ford-Walford y Gulland y con iteraciones de ajuste, ambas técnicas presentaron un alto coeficiente de determinación, pero tuvo mejor ajuste entre valores observados y calculados, de acuerdo con la suma de cuadrados del error; los resultados fueron: $\mathrm{L}_{\infty}=99,54$ $\mathrm{cm}, \mathrm{K}=0,205, \mathrm{t}=-0,060$. La longitud media para cada edad fue: edad 0 (menor a uno) $=1,22 \mathrm{~cm}$, edad $1=$ $19,47 \mathrm{~cm}$, edad $2=34,33 \mathrm{~cm}$, edad $3=46,43 \mathrm{~cm}$, edad $4=56,29 \mathrm{~cm}$ y edad $5=64,32 \mathrm{~cm}$. Se compararon estos resultados con los obtenidos hace 20 años para la misma zona, aplicándose el análisis de curvas coincidentes que mostró una reducción significativa en la longitud promedio de cada edad, que podría deberse a sobreexplotación. S. sierra tiene un $L_{\infty}$ menor en Manzanillo que en Mazatlán, debido probablemente a las diferencias climáticas, latitudinales o variaciones genéticas de las poblaciones. El índice alométrico de la relación peso-longitud fue isométrico, 3,031 y la longevidad 15 años.

Palabras clave: Distribución de frecuencia de longitud, sagittae, asterisci, von Bertalanffy, longevidad

\begin{abstract}
The artisanal fishery of sierra Scomberomorus sierra along the coast of Colima represents $1 \%$ of the total catch. From January 2003 to March 2004 morphometric data of 972 organisms and otoliths of 464 specimens were obtained to determine age and growth. Growth study was carried out by two methods: length frequency analysis and study of sagittae and asterisci otoliths. Both methods identified 5 age groups. Growth parameters of von Bertalanffy's equation were determined by Ford-Walford and Gulland methods and an iteration adjustment, both techniques showed a high determination coefficient, but the second was better between observed and calculated values according to the sum of squared error; the results obtained were: $\mathrm{L}_{\infty}=99.54 \mathrm{~cm}, \mathrm{~K}=0.205, \mathrm{t}_{0}=-0.060$. Mean size for each age was: age 0 (less than one) $=1.22 \mathrm{~cm}$, age $1=19.47 \mathrm{~cm}$, age $2=34.33 \mathrm{~cm}$, age $3=46.43 \mathrm{~cm}$, age $4=56.29 \mathrm{~cm}$ and age $5=64.32 \mathrm{~cm}$. Comparisons for this species were made with results from 20 years ago in the same area, using coincident curves test, showing a significant reduction in average length of each age; this may be caused by changes in the fishery or overexploitation, although growth parameters show the opposite trend. S. sierra has a lower $\mathrm{L}_{\infty}$ in Manzanillo than in Mazatlan, which could be explained by climatic, latitudinal differences or due to population's genetic variations. The allometric index from the weight-length relationship was isometric, 3.031 and longevity of 15 years.
\end{abstract}

Key words: Length frequency distribution, sagittae, asterisci, von Bertalanffy, longevity 


\section{INTRODUCTION}

The Pacific sierra, Scomberomorus sierra Jordan \& Starks, 1895 is an epipelagic neritic species which forms schools and spawns close to the coast on the continental shelf. Its entire distribution area goes from South California to Peru, including the Galapagos Islands. It feeds mainly on anchovies and sardines (Collette \& Nauen 1983). Its major captures occur in Mexico, where it is captured by sport fishers and abundant enough to sustain a commercial fishery (Fischer et al. 1995).

Captures of the Pacific sierra in Colima, Mexico, show two marked seasonal periods due to migration: in summer they swim north and in winter they migrate south (Márquez-Millán 1972). S. sierra is more abundant in the coasts of Manzanillo during February and March and from September to November (Chávez 1986). S. sierra is commercially considered a second class species with a price to fishers from $\$ 3.00$ to $\$ 4.00$ USD per kilogram.

Studies on its taxonomic description have been done by Castro-Aguirre (1978), Chirichigno et al. (1982) and Collette \& Nauen (1983). General features of its biology and fisheries are known by the studies of Márquez-Millán (1972), Chávez (1986), Espino-Barr et al. (1990) and Aguirre-Villaseñor et al. (2006), and an analysis of otolith's shape by Ramírez-Pérez et al. (2010).

Age determination studies are necessary to establish population structure by age groups, and to know the stock biomass increment due to their individual growth. These types of analysis allow comparative studies through time, and to determine the differences in the population structures due to environmental fluctuations and/or fishing exploitation (Espino-Barr et al. 2008).

Although the Pacific sierra is a commercially important species, studies on its population dynamics are limited. Age and growth studies of this species are ofwere carried out by Espino-Barr et al. (1990) in Manzanillo, Colima and by Aguirre-Villaseñor et al. (2006) in Mazatlán, Sinaloa. Therefore, this investigation provides, for the first time, data on age and growth of Pacific sierra in Manzanillo, Colima, analyzing length-frequency data and otoliths. Also, otolith asterisci analysis has never been done on this species. These results will help to establish fishery indices, and capture quotas that will help stakeholders to manage this fishing resource.

The objectives of this paper were: 1) to analyze polymodal curves in Pacific sierra's length frequency histograms, 2) determine time of growth ring formation in otoliths sagittae and asterisci, analyzing fast and slow growth borders, 3) calculate von Bertalanffy's growth constants parameters by length frequency analysis data and also those observed by Gallardo-Cabello et al. (2011) in the ring identification in otoliths sagittae and asterisci, 4) obtain the alometric index from the weight-length relationship, both total weight and eviscerated weight, and both asymptotic values of weight, 5) calculate $S$. sierra's longevity and, 6) compare results obtained in the present study with those obtained by Espino-Barr et al. (1990) and other authors.

\section{Material AND Methods}

From January 2003 to March 2004, individuals of S. sierra were obtained monthly from the commercial captures of the coastal fishery in Manzanillo, Colima, Mexico (1840' to $19^{\circ} 10^{\prime} \mathrm{N}$ and $103^{\circ} 45^{\prime}$ to $104^{\circ} 35^{\prime} \mathrm{W}$ ). Total length (TL) and weight (TW) from 972 organisms were obtained directly in situ throughout the study period. From these, 464 were transported to the lab, where total (TL) and standard length (SL), height (He) at the base of the dorsal fin, total (TW) and eviscerated weight (EW) and sex were registered for each organism. Individuals were captured with hand lines, troll and gillnet, which helped obtain different lengths and age groups.

The length frequency distribution was analyzed with the ELEFAN program of the FISAT package (Gayanilo et al. 1994) to obtain the average length of the polimodal curves corresponding to each age group. This method uses a goodness of fit index called $\mathrm{Rn}$ on a response surface, where the maximum value indicates the best combination of growth parameters.

The time of the growth ring formation was determined, observing whether the borders had slow or fast growth rings. In every case, otoliths were observed by transparency with transmitted light; the hyaline (translucent) zone corresponds to the slow growth band and the opaque zone to the fast growth band, which is in contrast with reflected light (Blacker 1974).

The average length of each growth ring determined by the analysis of the sagittae and asterisci otoliths by Gallardo-Cabello et al. (2011) was utilized to obtain the parameters of von Bertalanffy's (1938) growth equation. The observed values for sagittae were: for age $1=19.20$ $\mathrm{cm}$; age $2=35.14 \mathrm{~cm}$; age $3=45.80 \mathrm{~cm}$; age $4=56.20 \mathrm{~cm}$ and age $5=64.51 \mathrm{~cm}$. 
Von Bertalanffy's equation in the form of $\mathrm{L}=\mathrm{L}_{\infty}$ [1-e ${ }^{-}$ $\mathrm{K}(\mathrm{t}-\mathrm{t} 0)$ ], was utilized, where $\mathrm{L}=$ length, $\mathrm{L}_{\infty}=$ asymptotic length, $\mathrm{K}=$ growth factor and $\mathrm{t}_{0}=$ theoretic length at age 0 .

The parameters $\mathrm{L}_{\infty}$, K and $\mathrm{t}_{0}$ of von Bertalanffy's (1938) equation were obtained with Ford's (1933), Walford's (1946) and Gulland's methods (1964) and were adjusted by convergent iterations with Newton's algorithm with the solver program in Excel software (Microsoft 1992). The lowest value of a sum of the squared error determined the best adjustment.

The function $\mathrm{W}=\mathrm{a} \cdot \mathrm{L}^{\mathrm{b}}$ was used, where $\mathrm{W}=$ weight, $\mathrm{L}$ = length, to obtain the weight-length relationship, and a t- student test proved allometry (Zar 1996). The potential function was also used to find TL vs SL and He relationships, where the trend $\mathrm{b}$ tends to 1 , describing an isometric growth with those variables.

Growth data for length and weight-length relationship were used to obtain the weight at each age. Weight growth was obtained by substituting TL and $\mathrm{L}_{\infty}$ by TW and $\mathrm{W}_{\infty}$, in the von Bertalanffy's equation (1938). Taylor's equation (1958, 1960) was utilized to calculate the age limit or longevity (95\% of the $\left.\mathrm{L}_{\infty}\right): \mathrm{A}_{0.95}=\ln (1-0.95) / \mathrm{K}+\mathrm{t}_{0}$.

A test of coincident curves was carried out to detect differences between average lengths at each age (Haddon
2001) obtained in this investigation and those reported by Espino-Barr et al. (1990) 20 years ago in the same area.

\section{Results}

\section{BiOMETRIC RELATIONSHIPS}

The maximum value of TL was $97 \mathrm{~cm}$ and the minimum was $25 \mathrm{~cm}$, with a difference of $72 \mathrm{~cm}$ (Fig. 1). Total weight varied from $140 \mathrm{~g}$ to 5,400 g (Table 1). Mode was lower than average, implying a data distribution with positive asymmetric trend $\left(g_{1}=1.65\right)$, also with more values under the modes.

Table 1. Summary of size values of the measured variables: $T L=$ total length, $\mathrm{SL}=$ standard length, $\mathrm{He}=$ height, $\mathrm{TW}=$ total weight and $\mathrm{EW}=$ eviscerated weight / Resumen de valores de las variables medidas: $\mathrm{TL}=$ longitud total, $\mathrm{SL}=$ longitud estándar, $\mathrm{He}=$ altura, $\mathrm{TW}=$ peso total y $\mathrm{EW}=$ peso eviscerado

\begin{tabular}{lccrrr}
\hline & TL $(\mathrm{cm})$ & SL $(\mathrm{cm})$ & $\mathrm{He}(\mathrm{cm})$ & $\mathrm{TW}(\mathrm{g})$ & $\mathrm{EW}(\mathrm{g})$ \\
\hline Average & 49.63 & 39.78 & 7.84 & 738.19 & 681.50 \\
Maximum & 97.00 & 82.30 & 15.50 & 5400.00 & 4916.00 \\
Minimum & 30.00 & 24.00 & 4.80 & 140.00 & 21.00 \\
Mode & 44.00 & 35.00 & 7.00 & 504.00 & 382.00 \\
SD & 11.23 & 9.69 & 1.70 & 638.80 & 585.55 \\
$\mathrm{n}$ & 972 & 464 & 464 & 972 & 464 \\
\hline
\end{tabular}

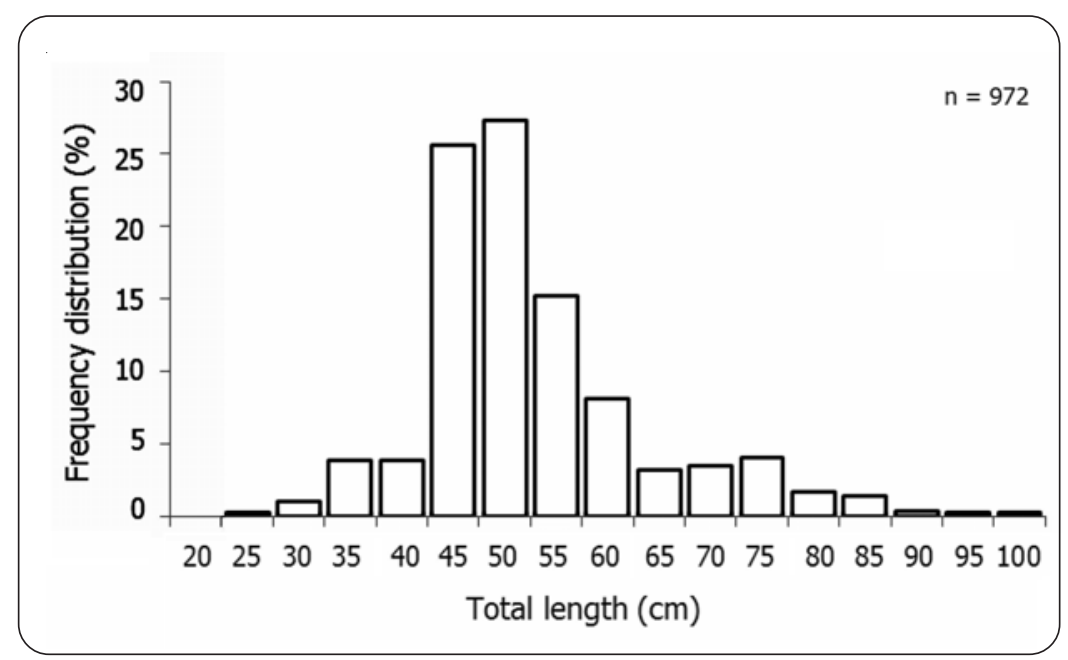

Figure 1. Frequency distribution of total length of S. sierra / Distribución de frecuencia de longitud total de S. sierra 
Data of the relationships between length, height and weight were highly significant, with $\mathrm{r}^{2}>0.90(P<0.05)$ (Table 2), but no differences were detected between sexes. Figure 2 shows the scatter diagram of the relation weightlength, adjusted by the potential model. The slopes of the relationships between lengths (TL, SL and $\mathrm{He}$ ) were not statistically different to one; and those between TL and TW and EW different to three.

\section{TIME OF GROWTH RINGS FORMATION OF THE SLOW AND FAST GROWTH BANDS}

S. sierra showed that a higher percentage of sagittae and asterisci otoliths with fast growth borders occurs from July to January, while the highest percentage with slow growth bands otoliths in the borders were observed from February to June (Fig. 3) ( $=132)$; this means that December is the birthday month, although some individuals start their growth ring from July on and other finish in May-June.

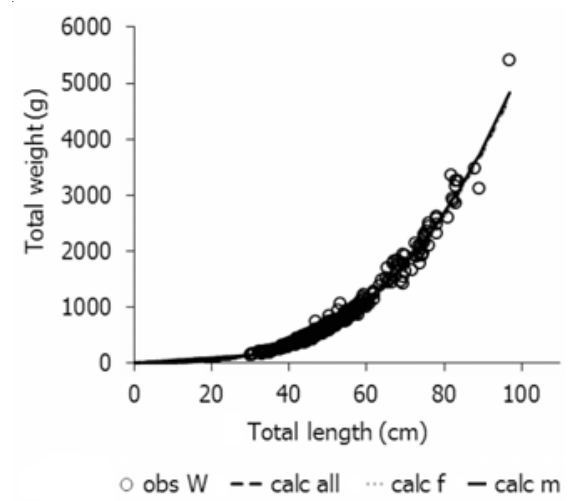

Figure 2. Weight-length relation by potential model / Relación peso-longitud ajustado por el modelo potencial

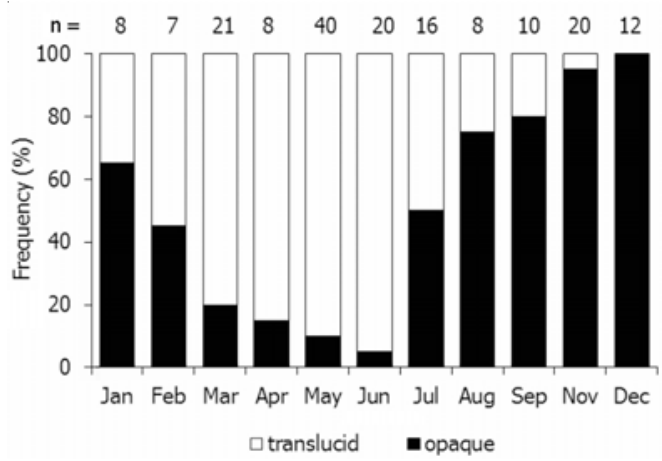

Figure 3. Monthly frequency of the slow-growth and fast-growth borders in the S. sierra sagittae and asterisci / Frecuencia mensual de los bordes de crecimiento lento y rápido en las sagittae y asterisci de S. sierra
Table 2. Morphometric relationships of the variables: $\mathrm{TL}=$ total length, $\mathrm{SL}=$ standard length, $\mathrm{He}=$ height, $\mathrm{TW}=$ total weight and EW = eviscerated weight / Relaciones morfométricas de las variables: $\mathrm{TL}=$ longitud total, $\mathrm{SL}=$ longitud estándar, $\mathrm{He}=$ altura, $\mathrm{TW}=$ peso total $\mathrm{y} \mathrm{EW}=$ peso eviscerado

\begin{tabular}{|c|c|c|c|}
\hline & Species & Females & Males \\
\hline \multicolumn{4}{|c|}{$\mathrm{TL} v s \mathrm{SL}$} \\
\hline b & 1.0620 & 1.0634 & 1.0615 \\
\hline $\mathrm{a}$ & 0.6282 & 0.6247 & 0.6292 \\
\hline$r^{2}$ & 0.9964 & 0.9969 & 0.9955 \\
\hline \multicolumn{4}{|c|}{$\mathrm{TL} v s \mathrm{He}$} \\
\hline $\mathrm{b}$ & 0.9408 & 0.9252 & 0.9680 \\
\hline $\mathrm{a}$ & 0.1991 & 0.2117 & 0.1793 \\
\hline$r^{2}$ & 0.9481 & 0.9569 & 0.9302 \\
\hline \multicolumn{4}{|c|}{ TL $v s$ TW } \\
\hline $\mathrm{b}$ & 3.031 & 3.031 & 3.043 \\
\hline $\mathrm{a}$ & 0.005 & 0.005 & 0.004 \\
\hline$r^{2}$ & 0.986 & 0.989 & 0.981 \\
\hline \multicolumn{4}{|c|}{$\mathrm{TL} v s \mathrm{EW}$} \\
\hline $\mathrm{b}$ & 3.056 & 3.017 & 3.056 \\
\hline $\mathrm{a}$ & 0.004 & 0.004 & 0.004 \\
\hline$r^{2}$ & 0.958 & 0.989 & 0.983 \\
\hline $\mathrm{n}$ & 464 & 225 & 238 \\
\hline
\end{tabular}

\section{ANALysis OF Length FREQUenCy}

Observed values of TL for each age ranged from $19.20 \mathrm{~cm}$ to $64.51 \mathrm{~cm}$ (Table 3), calculated with Ford-Walford and Gulland methods varied from 0.05 (at age 0 ) to $85.88 \mathrm{~cm}$ (at age 10); values were also adjusted to observed values by Solver which varied little from original values. Observed TL for each age obtained with FISAT's method showed lower values $(\mathrm{Rn}=0.350)$. Growth parameters for TL were: $\mathrm{L}_{\infty}=95.50 \mathrm{~cm}, \mathrm{~K}=0.207$ years $^{-1}$ and $\mathrm{t}_{0}=0.019$ (Fig. 4). The highest increment occurs during the first year of life, $17.55 \mathrm{~cm}$; during the next year growth rate decreases notably, $14.57 \mathrm{~cm}$ from ages 1 to $2 ; 11.85 \mathrm{~cm}$ from age 2 to age $3 ; 9.64 \mathrm{~cm}$ from age 3 to age $4 ; 7.83 \mathrm{~cm}$ from age 4 to age 5 and $6.37 \mathrm{~cm}$ from age 5 to age 6 .

\section{Analysis of otoliths}

Analysis of the sagittae and asterisci otoliths allowed the identification of 5 age groups. Growth parameters obtained by Ford-Walford-Gulland methods for TL were: $\mathrm{L}_{\infty}=96.82 \mathrm{~cm} ; \mathrm{K}=0.218$ years $^{-1} ; \mathrm{t}_{0}=-0.002$. Growth parameters obtained by solver iteration process were: $\mathrm{L}_{\infty}$ $=99.54 \mathrm{~cm} ; \mathrm{K}=0.205$ years $^{-1} ; \mathrm{t}_{0}=-0.060$. Growth from one age to the next was $18.24 \mathrm{~cm}$ from age 0 to age $1 ; 14.86 \mathrm{~cm}$ from age 1 to age 2; $12.10 \mathrm{~cm}$ from ages 2 to $3 ; 9.86 \mathrm{~cm}$ 
Table 3. Observed and calculated values of total length $(\mathrm{cm})$ and total and eviscerated weight (g) for each age group (years) of $\boldsymbol{S}$. sierra / Valores observados y calculados de la longitud total $(\mathrm{cm})$ y peso total y eviscerado (g) para cada grupo de edad (años) de S. sierra

\begin{tabular}{cccccrrr}
\hline $\begin{array}{c}\text { Age } \\
\text { (years) }\end{array}$ & $\begin{array}{c}\text { TL }(\mathrm{cm}) \\
\text { sagitta }\end{array}$ & $\begin{array}{c}\text { TL }(\mathrm{cm}) \\
\text { sagitta } *\end{array}$ & $\begin{array}{c}\text { TL }(\mathrm{cm}) \\
\text { sagitta ** }\end{array}$ & $\begin{array}{c}\text { TL }(\mathrm{cm}) \\
* * *\end{array}$ & $\begin{array}{c}\text { TW }(\mathrm{g}) \\
* *\end{array}$ & $\begin{array}{c}\text { EW }(\mathrm{g}) \\
* *\end{array}$ & $\begin{array}{c}\text { TL }(\mathrm{cm}) \\
* * * *\end{array}$ \\
\hline 0 & & 0.050 & 1.221 & & & & \\
1 & 19.20 & 19.005 & 19.470 & 17.55 & 40 & 35 & 29.73 \\
2 & 35.14 & 34.247 & 34.332 & 32.12 & 226 & 197 & 49.92 \\
3 & 45.80 & 46.503 & 46.436 & 43.97 & 564 & 497 & 64.01 \\
4 & 56.20 & 56.359 & 56.292 & 53.61 & 1011 & 894 & 73.83 \\
5 & 64.51 & 64.284 & 64.320 & 61.44 & 1514 & 1344 & 80.69 \\
6 & & 70.657 & 70.857 & 67.81 & 2030 & 1806 & 85.47 \\
7 & & 75.782 & 76.181 & 72.99 & 2528 & 2254 & 88.81 \\
8 & & 79.903 & 80.517 & 77.20 & 2990 & 2670 & 91.14 \\
9 & & 83.216 & 84.048 & 80.62 & 3406 & 3044 & 92.76 \\
10 & & 85.881 & 86.924 & 83.41 & 3771 & 3373 & 93.89 \\
\hline
\end{tabular}

*direct method with otoliths calculated with Ford-Walford and Gulland methods (Sparre \& Venema 1995).

** direct method with otoliths adjusted with solver (Microsoft 1992)

*** indirect method length frequency with FISAT (Gayanilo et al. 1994)

$* * * *$ indirect method length frequency with FISAT (Gayanilo et al. 1994)

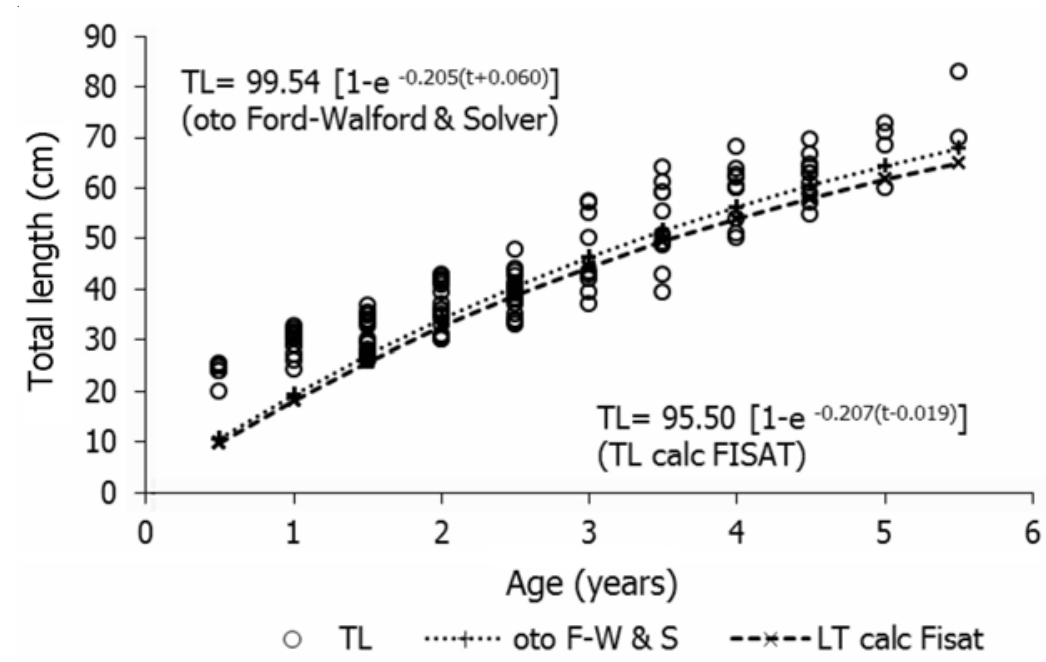

Figure. 4. Von Bertalanffy's growth curve in length for S. sierra by Ford-Walford with otolith readings and by length frequency with ELEFAN methods / Curva de crecimiento de von Bertalanffy's en longitud de S. sierra, por los métodos de Ford-Walford con lecturas directas de otolitos y por análisis de frecuencia de longitud con ELEFAN 
from ages 3 to $4 ; 8.03 \mathrm{~cm}$ from ages 4 to 5 and $6.53 \mathrm{~cm}$ from ages 5 to 6 . Figure 2 shows the growth curve of S. sierra according to von Bertalanffy's method.

The solver iterative process gave a better fit of the calculated equation to observed data of otoliths readings, than Ford-Walford and Gulland methods. The sum of square errors (SSE) between observed and calculated data by Ford-Walford and Gulland was 1.407, and that of the observed data and the resulting of solver process was SSE $=1.174$.

\section{GROWTH IN WEIGHT}

The allometric growth index value of the weight-length equation was isometric: $\mathrm{b}=3.031$ with total weight data and $b=3.056$ with eviscerated specimens (Table 2). The allometric growth index b was slightly higher for eviscerated weight, because data do not come from the same organisms in all cases.

\section{TheORETICAL GROWTH IN WEIGHT}

Values of calculated TW and EW have a slow growth during the first years of age, starting at 40 and $35 \mathrm{~g}$ (Table 3 , Fig. 5). After age 3 there is a very fast growth rate that starts to slow down after age 9 . The calculated asymptotic total weight was $\mathrm{Wt}_{\infty}=5,687.38 \mathrm{~g}$ and the eviscerated asymptotic weight $\mathrm{We}_{\infty}=5,104.49 \mathrm{~g}$.

\section{LONGeVITy (Age $\mathbf{A}_{0.95}$ )}

S. sierra reached $95 \%$ of its infinite length $\mathrm{L}_{\infty}$ in 14.55 years.

\section{Test Of COINCIDENT CURVES}

Statistical differences in the growth curve were found between the data reported by Espino-Barr et al. (1990) 20 years ago and the current results in the same area $\left(\mathrm{F}_{(2,12)}\right.$ $=6.45 ; P<0.05)$. Twenty years ago $S$. sierra grew faster $(\mathrm{K}=0.36)$ and had higher average sizes at each age even though the asymptotic length $\left(\mathrm{L}_{\infty}=96.51\right)$ was lower than parameters calculated in 2010 (Table 4).

Table 4. Growth curves comparison between years: data taken obtained from Espino-Barr et al. (1990) and results from this study, from the same area / Comparación de las curvas de crecimiento entre años: datos tomados de Espino-Barr et al. (1990) y los de este trabajo, de la misma zona de estudio

\begin{tabular}{cccccc}
\hline Year & $\mathrm{L}_{\infty}(\mathrm{cm})$ & $\mathrm{K}$ & $\mathrm{T}_{0}$ & $\mathrm{SC}$ & $\mathrm{d} . f$. \\
\hline 1990 & 96.51 & 0.360 & -0.023 & 33.541 & 7 \\
2010 & 99.54 & 0.205 & -0.060 & 1.357 & 4 \\
& $\mathrm{~F}_{(2,12)}=6.45$ & $P<0.05$ & & & \\
\hline
\end{tabular}

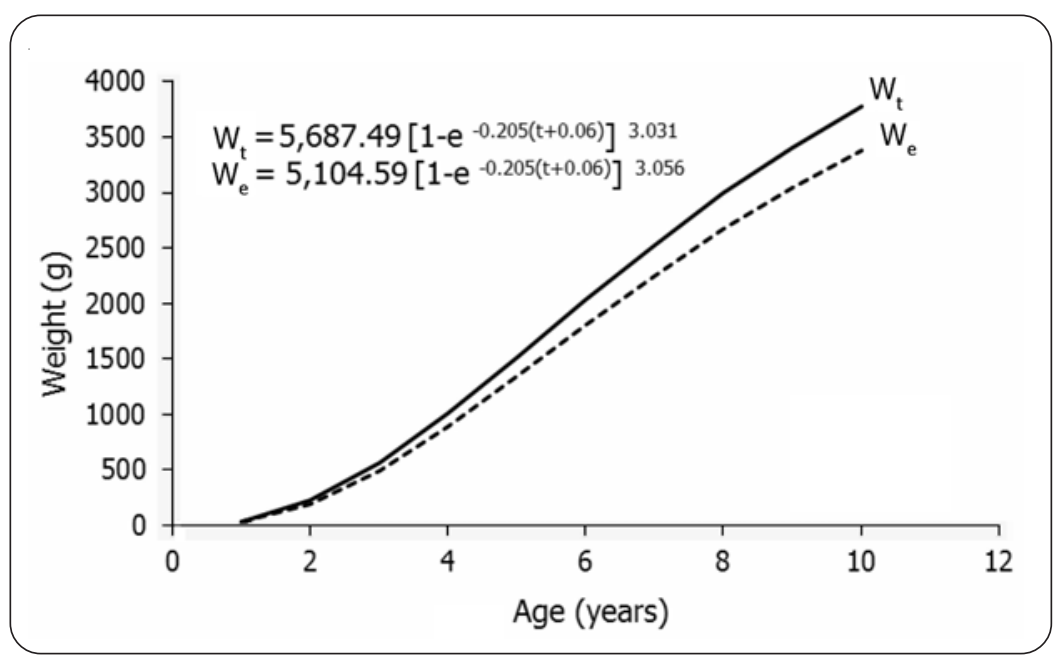

Figure 5. Von Bertalanffy's growth curve in total and eviscerated weight for S. sierra / Curva de crecimiento de von Bertalanffy en peso total y eviscerado de S. sierra 


\section{Discussion}

Each year a band of fast and slow growth are deposited on the otoliths sagittae and asterisci, validating the use of this structure to estimate age of $S$. sierra and its growth. This has also been found in other tropical species, where scales are not present (Gallardo-Cabello et al. 2006, 2007, 2011, Espino-Barr et al. 2006, 2008), allowing a good assessment of ageing, not always possible with scales.

The values obtained with the length frequency analysis were similar (although underestimated) to those found by the identification of growth rings in the sagittae and asterisci, which render age determination of S. sierra valid with both methods, and supporting each other (Joseph 1962). The differences emerged because of different methods utilized, a direct and an indirect approach.

Espino-Barr et al. (1990) also used the ELEFAN program (Gayanilo et al. 1994) for age determination of $S$. sierra obtaining the data listed in Table 3 . The values of the von Bertalanffy growth equation were: $\mathrm{L}_{\infty}=96.51 \mathrm{~cm}$; $K=0.36$ years $^{-1}, t_{0}=-0.023$ (Table 5). Even though the $L_{\infty}$ value was not very different from the one obtained in this study, $\mathrm{K}=0.36$ expresses a much faster growth, therefore the populations of $S$. sierra studied by Espino-Barr et al. (1990) reached its larger lengths faster, that is, at a lower age. This may be due to natural fluctuations in the environmental parameters in the past 20 years, which can cause changes in the food availability, affecting growth and recruitment. Overfishing can also cause size reduction for each age group (Macías-Zamora 1992, Ibáñez-Aguirre \& Álvarez-Hernández 1998), although it seems this is not the case. Capture of sierra in Manzanillo has declined sharply since 1980 , when 330 tons were fished (8.85\% of the total artisanal fisheries) compared to 15.6 tons (3.1\% of the total artisanal fisheries) in 2007. This reduction in the fishery has to be studied from the fishing effort point of view, to find a verifiable explanation.

Aguirre-Villaseñor et al. (2006) obtained for S. sierra in the coast of Mazatlán, Sinaloa, values of $L_{\infty}=108.30$ $\mathrm{cm}$, and $\mathrm{K}=0.15$ years $^{-1}$ (Table 5). Compared to the obtained values, our $\mathrm{L}_{\infty}$ was lower $(95.50 \mathrm{~cm})$ and $\mathrm{K}$ higher (0.207), which is explained by the fact that $\mathrm{K}$ index value is inversely proportional to $\mathrm{L}_{\infty}$. Similarly when the sea temperature rises, so does the index value $\mathrm{K}\left(25^{\circ} \mathrm{C}\right.$ in Mazatlán and $27^{\circ} \mathrm{C}$ in Manzanillo), in accordance with Taylor $(1958,1960)$ who states that the K index has a directly proportional relationship to the temperature.

Domínguez-López et al. (2010) reported high mitochondrial genetic diversity (mtDNA) for S. sierra and a highly significant divergence throughout the eastern Pacific. They found two genetically different groups: one in the northern area (Sinaloa) and the second in the central area (Oaxaca and Chiapas). We consider that our results in Manzanillo, Colima belong to the central area, because it is found under the southern limit of the California Current and very close to the latitude of the coasts of Oaxaca and Chiapas.

Table 5. Growth parameters of the von Bertalanffy equation for Scomberomorus sierra reported by different authors (longevity values were calculated by this research) / Parámetros de crecimiento de la ecuación de von Bertalanffy de Scomberomorus sierra reportados por diferentes autores (los valores de longevidad fueron calculados en este trabajo)

\begin{tabular}{lcccc}
\hline & Espino-Barr et al. & Aguirre-Villaseñor et al. & This paper & This paper \\
\hline Year & 1990 & 2006 & 2010 & 2010 \\
Area & Colima & Gulf of California, Mazatlán & Central Mexican Pacific & Central Mexican Pacific \\
Method & TL (ELEFAN) & LF & TL (ELEFAN) & TL (otoliths) \\
$\mathrm{L}_{\infty}(\mathrm{cm})$ & 96.51 & 108.30 & 95.50 & 99.54 \\
$\mathrm{~K}$ & 0.360 & 0.150 & 0.207 & 0.205 \\
$\mathrm{t}_{0}$ & -0.023 & 0.0001 & 0.019 & -0.060 \\
longevity (years) & 8 & 20 & 14 & 15 \\
$\mathrm{fi}_{\mathrm{i}}$ & 3.525 & 3.245 & 3.276 & 3.308 \\
$\mathrm{~T}^{\circ} \mathrm{C}$ & 26.5 & & 26.5 & 26.5 \\
\hline
\end{tabular}


It is important to point out that the asynchronic spawning in distant areas can determine isolation of the stocks, and therefore the formation of genetically different populations (Shoji et al. 2005). Nevertheless, the spawning periods of $S$. sierra in Manzanillo show two seasons, from March to May and from August to September (Nava 2008); this is similar to the season in Sinaloa, where Aguirre-Villaseñor et al. (2006) reported that it occurs from July to September. The population differences may have occurred at the same time than glacial-interglacial episodes in the Pleistocene, but also can be largely related with the changes of the surface sea temperature (SST), upwelling areas and with ENSO events (Domínguez-López et al. 2010). Organisms utilized to study fishery dynamics come from partially biased samples, due to the catching methods; besides, these methods catch whatever fish is present, which depend on temperature of the water, currents, time of the year, fish vulnerability to fishing gears and presence of other species (predators, competitors, prey).

These periodic changes in the environment can also alter growth mechanisms in different regions, as mentioned by Ramírez-Pérez et al. (2010), who found three different groups of $S$. sierra in the areas of Guaymas, Mazatlan and Bahía Magdalena, based on the method of procrustes superimposition in the saggitae otolith.

According to the allometric index of the length-weight relationship, our values were similar to those found by Espino-Barr et al. (1990), who reported an isometric index of 3.08. S. sierra's longevity calculated by Espino-Barr et al. (1990) of 8 years, was lower than that reported in this study (14 years). The value calculated with data from Aguirre-Villaseñor et al. (2006) was of 20 years old (Table 5).

There are no enough results in this study to corroborate a hypothesis that this species is an overfished resource, although catches have remarkably declined. Other analysis using growth fishery parameters must be utilized to analyze the state of health of the species in the central Mexican Pacific coast.

\section{Conclusions}

Length frequency analysis by ELEFAN method showed that the polimodal curves of the 5 growth rings observed in the otoliths sagittae and asterisci, identified age groups by direct (otoliths) and indirect methods (length frequency). The border analysis in otoliths sagittae and asterisci determined that each year a fast and slow growing band is formed, so $S$. sierra's age determination by these hard parts is valid. The von Bertalanffy's constant values were $\mathrm{L}_{\infty}=99.54 \mathrm{~cm}, \mathrm{~K}=0.205$ and $\mathrm{t}_{0}=-0.060$, and the weight-length relationship was isometric. Asymptotic total weight value was $\mathrm{Wt}_{\infty}=5,687.38 \mathrm{~g}$ and eviscerated weight $\mathrm{We}_{\infty}=5,104.49$ g. S. sierra lives up to 14.55 years.

Twenty years ago larger sizes for each age group were obtained for S. sierra in Manzanillo, Colima, México, than those found in the present study, but the allometric growth index found in this study is very similar to the one reported 20 years ago in this locality. S. sierra reaches a smaller infinite length and a higher catabolic index in Manzanillo, Colima than in Mazatlán, Sinaloa.

\section{LITERATURE CITED}

Aguirre-Villaseñor H, E Morales-Bojórquez, RE MoránAngulo, J Madrid-Vera \& MC Valdez-Pineda. 2006. Indicadores biológicos de la pesquería de sierra (Scomberomorus sierra) al sur del Golfo de California, México. Ciencias Marinas 32(3): 471-484.

Blacker RW. 1974. Recent advances in otolith studies. In: Harden-Jones E (ed). Sea fisheries research, pp. 67-90. Elek Science, London.

Castro-Aguirre JL. 1978. Catálogo sistemático de los peces marinos que penetran a las aguas continentales de México, con aspectos zoogeográficos y ecológicos. Departamento de Pesca, Instituto Nacional de la Pesca, Serie Científica 19: 1-298.

Chávez RJE. 1986. Análisis preliminar biológico-pesquero de la sierra, Scomberomorus sierra, Jordan y Starks, 1895, en la bahía de Manzanillo, Colima. Tesis de Biología, Escuela Nacional de Estudios Profesionales-Iztacala, Universidad Nacional Autónoma de México, México, 52 pp.

Chirichigno N, W Fischer \& CW Nauen. 1982. INFOPESCA. Catálogo de especies marinas de interés económico actual o potencial para América Latina. Parte 2. Pacífico Centro y Suroriental. SIC/82/2: 1-588. FAO/PNUD, Roma.

Collette BB \& CE Nauen. 1983. FAO Species Catalogue Vol.2. Scombrids of the world. An annotated and illustrated catalogue of tunas, mackerels, bonitos and related species known to date. FAO Fisheries Synopsis 125(2): 1-137.

Domínguez-López M, M Uribe-Alcocer \& P Díaz-Jaimes. 2010. Phylogeography and historical demography of the Pacific sierra mackerel (Scomberomorus sierra) in the Eastern Pacific. BMC Genetics 11: 1-12.

Espino-Barr E, M Cruz-Romero \& A Garcia-Boa. 1990. Biología pesquera de tres especies de la familia Scombridae en el litoral de Colima, México. In: Dailey M \& H Bertsch (eds). Memorias del VIII Simposium de Biología Marina. Ensenada, México, pp. 65-74. Universidad Autónoma de Baja California, México. 
Espino-Barr E, M Gallardo-Cabello, A Garcia-Boa, EG Cabral-Solís \& M Puente-Gómez. 2006. Morphologic and morphometric analysis and growth rings identification of otoliths: sagitta, asteriscus and lapillus of Caranx caninus (Pisces: Carangidae) in the coast of Colima, Mexico. Journal of Fisheries and Aquatic Science 1(2): 157-170.

Espino-Barr E, M Gallardo-Cabello, EG Cabral-Solís, A Garcia-Boa \& M Puente-Gómez. 2008. Growth of the Pacific jack Caranx caninus (Pisces: Carangidae) from the coast of Colima, México. Revista de Biología Tropical 56(1): 171-179.

Fischer W, F Krupp, W Schneides, C Sommer, KE Carpenter \& UH Niem. 1995. Guía FAO para la identificación de especies para los fines de la pesca. Pacífico Centro Oriental. Vertebrados, Vols. II y III, pp. 644-1813. FAO, Roma.

Ford E. 1933. An account of the herring investigations conducted at Plymouth during the years from 1924 to 1933 . Journal of the Marine Biological Association of the United Kingdom 19: 305-384.

Gallardo-Cabello M, E Espino-Barr, A Garcia-Boa, EG Cabral-Solís \& M Puente-Gómez. 2006. Morphologic and morphometric analysis and growth rings identification of otoliths: sagitta, asteriscus and lapillus of Caranx caballus (Pisces: Carangidae) in the coast of Colima, Mexico. International Journal of Zoological Research 2(1): 34-47.

Gallardo-Cabello M, E Espino-Barr, A Garcia-Boa, EG Cabral-Solís \& M Puente-Gómez. 2007. Study of the growth of the green jack Caranx caballus Günther 1868, in the coast of Colima, México. Journal of Fisheries and Aquatic Science 2(2): 131-139.

Gallardo-Cabello M, E Espino-Barr, RA Nava-Ortega, A Garcia-Boa, EG Cabral-Solís \& M Puente-Gómez. 2011. Analysis of the otoliths, sagittal, asteriscus and lapillus of Pacific sierra Scomberomorus sierra (Pisces: Scombridae) in the coast of Colima México. Journal of Fisheries and Aquatic Science 6(4): 390-403.

Gayanilo FC, P Sparre \& D Pauly. 1994. The FAO-ICLARM Stock Assessment Tools (FiSAT) user's guide. FAO Computarized Information Series, Fisheries 6: 1-186. FAO, Roma.

Gulland JA. 1964. Manual of methods of fish population analysis. FAO Fisheries Technical Paper 40: 1-60.

Haddon M. 2001. Modelling and quantitative methods in fisheries, 406 pp. Chapman \& Hall, Washington.

Ibáñez-Aguirre AL \& SA Álvarez-Hernández. 1998. De empequeñecerse para crecer. Contactos 27: 5-8.
Joseph DC. 1962. Growth characteristics of two Southern California Surffishes, the California corbina and spotfin croaker, Family Sciaenidae. The Resources Agency of California. Department of Fish and Game. Fishery Bulletin 119: 1-54.

Macías-Zamora R. 1992. Relaciones entre la pesca deportiva y comercial del pez vela (Istiophorus platypterus), en el Pacífico mexicano. Tesis de Maestría en Ciencias, Centro de Interdisciplinario de Ciencias Marinas, Instituto Politécnico Nacional, 71 pp.

Márquez-Millán R. 1972. Sierra del Pacífico. Unidades de producción. En: INP (ed). Diagnóstico de la situación actual de las pesquerías de México, pp. 171-182. Programa de Investigaciones y Fomento Pesquero. México/PNUD/FAO, Departamento de Pesca, Instituto Nacional de la Pesca, México.

Microsoft. 1992. Manual de usuario. Referencia de funciones. Microsoft Excel Versión 4.0 para Windows, 702 pp. Microsoft Corporation USA, Redmond.

Nava R. 2008. Criterios para la modificación de la luz de malla para optimizar la pesca de Scomberomorus sierra (Jordan \& Starks, 1895), en el estado de Colima. Tesis Maestría en Ciencias, Facultad de Ciencias Marinas, Universidad de Colima, 75 pp.

Ramírez-Pérez JS, C Quiñónez-Velázquez, FJ GarcíaRodríguez, R Félix-Uranga \& FN Melo-Barrera. 2010. Using the shape of sagittal otoliths in the discrimination of phenotypic stocks in Scomberomorus sierra (Jordan \& Starks, 1895). Journal of Fisheries and Aquatic Science 5(2): 82-93.

Shoji J, M Tsutomu \& M Tanaka. 2005. Larval growth and mortality of Japanese Spanish mackerel (Scomberomorus niphonius) in the central Seto Inland Sea, Japan. Journal of Marine Biology Association of the United Kingdom 85: 1255-1261.

Sparre P \& SC Venema. 1995. Introducción a la evaluación de recursos pesqueros tropicales. Parte 1 - Manual. FAO Documento Técnico de Pesca 306/1: 1-420.

Taylor CC. 1958. Cod growth and temperature. Journal du Conseil 23(3): 366-370.

Taylor CC. 1960. Temperature, growth and mortality - the Pacific cockle. Journal du Conseil 26(1): 177-124.

Von Bertalanffy L. 1938. A quantitative theory of organic growth (inquiries on growth laws. II). Human Biology 10(2): 181-213.

Walford LA. 1946. A new graphic method of describing the growth of animals. The Biological Bulletin 90(2): 141-147.

Zar JH. 1996. Biostatistical analysis, 662 pp. Prentice Hall, Upper Saddle River.

Received 28 September 2011 and accepted 18 June 2012

Associate Editor: Mauricio Landaeta D. 